\title{
JOHN CAIUS AND THE LINACRE TRADITION
}

\author{
by
}

\author{
VIVIAN NUTTON*
}

To TALK of Thomas Linacre and John Caius together in the same paper is almost like commending a saint and a sinner in the same sermon. Linacre is universally praised by his contemporaries and by modern scholars alike, while Caius in his writings and in his daily relationships seems petulant and domineering, with a dislike of Welshmen, whom he excluded from his refounded College along with the blind, the deaf, the halt, the lame, and sufferers from grave or incurable diseases. ${ }^{1}$ Linacre's achievement was to drag medicine in this country into the sixteenth century; the effect of Caius' example, it is alleged, was firmly to keep it there for a further two centuries. Caius was a reactionary in many ways, of that there is no doubt-his preference for the old rituals and institutions was strengthened by his experience of unruly junior fellows and boisterous undergraduates given to games and drinking, who preferred to spend their money on fashionable clothes that would soon wear out rather than on books that would endure. ${ }^{2}$ Yet his attachment to the past was not just wistful yearning for a bygone age: he was aware of the positive benefits to the present to be gained by adherence to an active tradition, that of the medical humanism of Linacre, whose memory he venerated and whose tomb he repaired and, in his will, commanded his executors to clean and mend. ${ }^{3}$ His medical fellowships at his college, his proud and autocratic rule of the College of Physicians, cannot be understood without Linacre's example, and Caius would assuredly have been delighted and flattered by Bullein's praise of him for "shewyng himself to be the seconde

*Vivian Nutton, M.A., Ph.D., Wellcome Institute for the History of Medicine, 183 Euston Road, London NW1 2BP.

This paper is a revised version of a lecture given at Oxford and Cambridge. I am grateful to Philip Grierson, Charles Webster, Roger French, and, in particular, Andrew Cunningham for their comments and criticism.

The various writings of Caius (with the exception of his editions and translations) are cited according to the pagination of E. S. Roberts, The works of John Caius, M.D., with a memoir of his life by J. Venn, Cambridge University Press, 1912. The versions and translations are to be found in Galeni libri aliquot Graeci, Basle, H. Froben, N. Episcopus, 1544; Opera aliquot et versiones, Louvain, A. M. Bergagne, 1556 .

$1 \mathrm{~J}$. Venn, A biographical history of Gonville and Caius College, Cambridge University Press, 1901, vol. 3, p. 357, Statute 12: although "syphilitic" (gallicus) might be preferable in the context, I have as yet found no example of the adjective used on its own with that meaning, and the word, added above the line in the manuscript, is unmistakably "wallicus"; see J. Cule, "A note on Hugo Glyn and the statute banning Welshmen from Gonville and Caius College', National Library of Wales Journal, 1969, 16: 185-191 and pl. XVI, 7.

Historia Cantebrigiensis Academiae, I, pp. 74-77; cf. Statutes (op. cit, note 1 above), p. 360, nos. 20,22 and 23.

De libris propriis, p. 77; Annales Collegii Medicorum, pp. 7, 43: Venn, Works, op. cit., note* above, pp. 11, 62, 63, 74 . 


\section{Vivian Nutton}

Linacar, whose steppes he foloweth reueilyng unto this fraternitie [of surgeons] the hidden iuelles and precious threasours of C. L. Galenus". Linacre's place, thanks to his recent advocates, needs little defence: ${ }^{5}$ my energies in this paper will be devoted first to an investigation of the humanist tradition in medicine in this country, and second to a closer examination of John Caius in the context of sixteenth-century European medicine. I shall suggest that much of the scorn directed upon him by modern scholars derives from a fallacious historical perspective, the temptation to view 1559 in the light of 1628 , even to the ludicrous extent of making William Harvey attend Caius' dissections and praising Caius for his joint foundation of the Lumleian lectures eight or nine years after his death. ${ }^{6}$

Humanist medicine may be defined as that movement in medicine in the sixteenth and seventeenth centuries which sought to purify medicine of complex and unnecessary accretions by a return to the classical sources of humoral therapy, and in particular to Hippocrates and his great systematic interpreter, Galen. It was a movement at one and the same time aesthetic, practical, academic, progressive, at least in the context of the first half of the sixteenth century, and emotional. Emotional, because the belief that the medical authors of classical antiquity ipso facto conveyed more of value than their medieval and Arab equivalents was not always based on evidence, as practical Arabists like Laurent Fries were quick to point out, and because the jettisoning of accumulated medical wisdom threw overboard much that was valuable as well as much that was worthless. ${ }^{7}$ It was aesthetic, because the superiority of the new learning rested in part on the elegance of its traditional formulations, on a classical rather than on a bastard Latin, and because the new italic and Roman founts in which it was printed were intended to give greater pleasure to the eye than the crabbed and cumbersome manuscripts of the Middle Ages. To a Renaissance humanist, the 1490 edition of Galen, with its two close-packed columns and many abbreviations, might seem to represent gothic barbarism at its worst when contrasted with the beautiful printing of Linacre's translations or the Juntine folios. ${ }^{8}$

- W. Bullein, Bulleins Bulwarke of defence against all sicknes, sorenes and woundes . . . (Here after insueth a little dialogue betwene twoo men, the one called Sorenes, and the other Chirurgj . . .), London, Jhon Kyngston, 1562, (Dial.), fol. iiiir.

B F. Maddison, M. Pelling, and C. Webster (editors), Essays on the life and work of Thomas Linacre, c. 1460-1524, Oxford University Press, 1977.

- C. D. O'Malley, 'The relations of John Caius with Andreas Vesalius and some incidental remarks on the Giunta Galen and on Thomas Geminus', J. Hist. Med., 1955, 10: 167, in the first instance mistaking College for man, and in the second confusing Caius with Caldwell.

' L. Fries, Defensio medicorum principis Avicennae ad Germaniae medicos, Strasbourg, J. Knoblouch, 1530; L. Thorndike, $A$ history of magic and experimental science, New York, Columbia University Press, 1941, vol. 5, p. 436 f.; E. Wickersheimer, 'Laurent Fries et la querelle de l'arabisme en médecine (1530)', Les Cahiers de Tunisie, 1955, 9: 96-103; cf. also for the sort of arguments raised against the humanists, J. H. Overfield, 'Scholastic opposition to Humanism in Pre-Reformation Germany', Viator, 1976, 7: 391-420. One topic on which Caius strongly opposed the humanists was over their new (but in fact ancient) pronunciation of Greek and Latin, in which he preferrea to follow the traditional (but medieval) usage and custom and, in his College Statutes, 21, p. 360, required of every member of the College, in public and private speech, the time-honoured pronunciation, see J. B. Gabel, John Caius, De pronunciatione Graecae et Latinae linguae . . ., Leeds, Scolar Press, 1968, pp. 1-7.

${ }^{8}$ For humanist (especially Italian) views on script, see S. Rizzo, Il lessico filologico degli umanisti, Rome, Edizioni di storia e letteratura, 1973, pp. 130-137, esp. p. 133 f., on "gothicae/barbarae litterae". 


\section{John Caius and the Linacre tradition}

Humanist medicine was academic, not just in the sense that its leading exponents were university teachers or doctors moving in highly-cultivated court circles-that had been true of late medieval medicine-but because its methods were based on the new learning of the classical revival. Philology, occasionally supplemented by direct observation, was the chief tool of the new movement; and, in purely academic terms, the humanist physicians and naturalists of the sixteenth century were in their philological techniques more sophisticated than their more celebrated colleagues, the editors of classical literary texts. ${ }^{9}$ Ermolao Barbaro and Collenucci's work on Pliny, Mattioli's commentary on Dioscorides, and Foes' Oeconomia Hippocratica display a subtler appreciation of the relationship between ancient words and things than that possessed by any philologist before J. J. Scaliger, and he was the son of a famous humanist physician. Their interest in discovering manuscripts resulted in intimations of a method of textual criticism and of evaluating manuscripts that was not surpassed until the nineteenth century. Giovanni Manardi, pupil and successor of Niccold Leoniceno as professor of medicine at Ferrara, rejected a simple enumeration of manuscripts in favour of a form of stemmatics, ${ }^{10}$ and Caius himself was well aware of the danger of scribal copyists who allowed their thoughts to influence their hands. That was his objection to the manuscript notes used by Vesalius as a basis for emendations in the texts of Anatomical procedures. ${ }^{11}$

At least for a time, this textual, humanist, approach to medicine was practical and progressive. ${ }^{12}$ For one thing, the new Latin versions were to the layman, and possibly also to the physician, easier to read and understand than their predecessors: there were no strange words coined direct from Arabic or Greek: some translators tried to achieve accuracy and intelligibility without recourse to strange neologisms, although fully to appreciate the nuances of Linacre's versions would, as Durling has shown, require as wide a literary culture as the translator's, which was very broad indeed. ${ }^{13}$ For another, the mass of translations that followed the publication in 1525 of the first Greek edition of the collected works of Galen made generally available far more of the writings of Galen than ever before. Although the standard works of Galen that had been included in the Articella (the Art, the Commentaries on Prognostic, Aphorisms, and Regimen in acute diseases), continued to form part of the university medical curriculum, the advent of printing and the possibility of providing pocket editions of individual treatises meant that the interested student could obtain

\footnotetext{
- For the development of philological methods at this time, see B. M. Metzger, The text of the New Testament, Oxford, Clarendon Press, 1964, pp. 95-110; E. J. Kenney, The classical text, Berkeley, University of California Press, 1974, pp. 21-87; A. J. Grafton, 'From Politian to Pasquali', Journal of Roman Studies, 1977, 67: 171-176.

${ }_{10} \mathrm{G}$. Manardi, Epistularum medicinalium libri XX, Basle, Isingrin, 1540, Ep. 19.5 (1535), to be classed with other "isolated insights" into stemmatic relationships, Kenney, op. cit., note 9 above, p. $10 f$.

11 De libris propriis, p. 76; Galeni libri ...., p. 320.

12 W. Pagel, 'Medical humanism - a historical necessity in the era of the Renaissance', in Maddison, Pelling, and Webster, op. cit., note 5 above, pp. 375-386; contrast, S. Lindroth, 'Medicin och humanism under renässensen', Lychnos, 1950-51, pp. 163-181; G. Eis, Forschungen zur Fachprosa, Berne, Francke, 1971, pp. 68-70, 74-76.

12 R. J. Durling, 'Linacre and medical humanism', in Maddison, Pelling and Webster, op. cit., note 5 above, pp. 76-106, esp. pp. 99-103. It should not be forgotten that for many humanists, like Caius and Cornarius, Latin versions were a second-best substitute for the Greek originals, which all humanist physicians should aspire to read.
} 


\section{Vivian Nutton}

a wider and possibly cheaper range of tracts than had been available in the Middle Ages. ${ }^{14}$ Then some major treatises were effectively unknown in the West, and manuscripts of the minor works, many translated only by Niccold da Reggio, were very few and far between. Even where they existed, they were not always appreciated: a manuscript of twenty-one tracts of Galen rested for years rotting and smelling in a cupboard at the back of the sacristy in the Austin Priory in Nuremberg until rescued for ten florins by the doctor and bibliophile, Hartmann Schedel..$^{15}$ As a result of the new learning, new syntheses could be made without the strait-jacket of Arabic intermediaries, and the essential qualifications included by Galen but omitted by the Arabs could once more be made to an art that was at one and the same time exact and dependent on intuition. It should not be forgotten also that since much university teaching was of itself theoretical, the recovery of Galenic and Hippocratic doctrine, especially in such new-found texts as On the opinions of Hippocrates and Plato, permitted a much more accurate restatement of theories which all, save the Paracelsians, accepted as the basis for medical practice. If, as happened with anatomy, the resulting construction appeared faulty or incomplete, the defensive argument could no longer then be raised that the true Galen was still to be discovered. And if, as some argued, the Galenic system was over-rigid, it was always open to a teacher to use the dark sentences of the newly translated Hippocrates as a basis for a freer and broader synthesis. ${ }^{16}$

Finally, and at least in part as a result of the new humanist medicine, there is the increasing importance given to anatomy. The cult of Galen brought with it the cult of anatomy, which he regarded as essential for all doctors and in which he claimed, with some justice, to excel all his predecessors. The Renaissance translations included one major new text on anatomy, the first half of Anatomical procedures, which was known to the Middle Ages only in a mangled summary from the Arabic. Its editors and translators had at least a passing interest in anatomy: the first translation, that of the unfortunate Greek, Chalcondylas, was revised for publication after his death by a very competent anatomist, Berengario; ${ }^{17}$ the second translator, Guinther of Andernach, carried out public dissection of human corpses at Paris and encouraged others, like Vesalius, to practise anatomy for themselves. ${ }^{18}$ Among the later editors,

14 R. J. Durling, 'A chronological census of the Renaissance editions and translations of Galen', J. Warburg and Courtauld Institutes, 1961, 24: 230-235; idem, 'An early manual for the medical student and the newly fledged practitioner; Martin Steinpeis' Liber de modo studendi seu legendi in medicina (Vienna, 1500)', Clio Medica, 1970, 5: 7-33.

${ }^{15}$ The (whole?) manuscript is now in Munich, Bayerische Staatsbibliothek, CLM 5, with Schedel's note on fol. 1: see also, R. Stauber, Die Schedelsche Bibliothek, Freiburg-i.-Br., Herder Verlag, 1908, p. 249; O. Meyer, 'Hartmann Schedel', Med.-hist. J., 1969, 4: 55-68, see p. 59, who slightly mistranslates the Latin.

${ }^{16}$ The Aphorisms, Epidemics, Prognostic, and Nature of man continued to form the staple diet of Italian lecture-courses for many years, and an unscholarly faith in Hippocrates has lasted until the present day, although the various transformations of Hippocrates from the Renaissance, through Sydenham, to today have not received a satisfactory modern study: cf. on one aspect, I. M. Lonie, 'Cos versus Cnidos and the historians', Hist. Sci., 1978, 16: 42-92.

${ }^{17}$ Galeni libri anatomici, Bologna, G. B. Phaelli, 1529, E. Legrand, Bibliographie Hellénique, Paris, Didot, 1885, vol. 2, pp. 331-3; vol. 3, p. 326f.; L. R. Lind, Studies in pre-Vesalian anatomy, Philadelphia, American Philosophical Society, 1975, pp. 159-165.

18 C. D. O'Malley, Andreas Vesalius of Brussels, Berkeley and Los Angeles, University of California Press, 1964, pp. 54-61. 


\section{John Caius and the Linacre tradition}

Caius owned the surgical treatises of Tagault and Vigo as well as Vesalius' Fabrica, performed annual dissections before the Barber-Surgeons for almost twenty years, and, it may be surmised, was behind the permission given to the College of Physicians in 1564-65 to dissect four corpses a year. ${ }^{19}$ In his statutes for his College he laid down that two anatomies should be performed yearly by a fellow of the College, and made provision for the reverent burial of the corpse afterwards. ${ }^{20}$ Even Vesalius, who revised Anatomical procedures and On the dissection of veins and arteries for the 1541 Juntine edition, and who by 1543 was convinced of the erroneous basis of Galen's human anatomy, could pursue, while rejecting Galen, the humanist aim of restoring the lost "prisca anatomia" of the early Alexandrian anatomists. ${ }^{21}$ Even if Galen is abandoned, it is still a classical ghost that is conjured up.

In England the humanist physicians, from Linacre onwards, had generally spent some time in Italy, which was in the sixteenth century in advance of the rest of Europe, not just in its medical theories, but in its system of medical education, its provision for public health, and the organization and status of its medical profession. A visit to Italy not only strengthened one's links with the classical heritage, it offered a modern medical ideal that might be put into practice on one's return. Italian public health officials were held up by Caius for approval and imitation;22 Linacre's College of Physicians derived largely from Italian models; and its revised statutes, with their emphasis on Galenic theory, and Caius' attempts to secure its primacy as the body for the universal regulation of medicine in England, represented the consolidation of Linacre's work along the best continental or Italian lines. ${ }^{23}$ The Galenic texts set for examination by the college were far from being reactionary when compared with the set texts in universities on the continent. ${ }^{24}$ At Heidelberg, the syllabus was modernized in favour of the Greeks only in 1558:25 the curriculum at Ingoldstadt and Freiburg was similarly changed, but in 1571 and 1577 they were both compelled by their territorial ruler to revert to one based upon "the old, more solid medicine", with a greater admixture of Rhazes and Avicenna, and the exclusion of all modern

10 P. Grierson, 'John Caius' library', Biographical history of Gonville and Caius College, Cambridge University Press, 1978, vol. 7, catalogue nos. 18, 32, 7; J. Caius, De libris propriis, p. 91.

${ }_{20}$ Venn, op. cit., note 1 above, p. 367, Statute 42: cf. also p. 253.

21 A. Vesalius, De humani corporis fabrica, Basle, J. Oporinus, 1543, fol. 3v; L. Edelstein, Ancient medicine, Baltimore, Md., Johns Hopkins Press, 1967, pp. 441-454. Vesalius' insistence on returning to the age of Herophilus, Marinus, and Andreas reveals an ahistorical conflation of four hundred years of anatomy.

22 A counseill against the sweate, p. 21, praising "certein masters of helth in euery citie or town": cf. C. Cipolla, Public health and the medical profession in the Renaissance, Cambridge University Press 1976.

a. Webster. 'Thomas Linacre and the foundation of the College of Physicians', in Maddison, Pelling, and Webster, op. cit., note 5 above, pp. 198-222; G. Whitteridge, 'Some Italian precursors of the Royal College of Physicians', J. R. Coll. Physcns, 1977, 12: 67-80, may be too restrictive in her choice of Padua and Venice alone as models.

24 The date of the fourfold examination based exclusively on Galenic texts is uncertain, probably 1541-42, see G. N. Clark, A history of the Royal College of Physicians of London, Oxford University Press, 1964, p. 98 f.; it was certainly confirmed in Caius' reformed statutes of 1563 (ibid., p. 89)., One should not forget that the College examination was new and of practitioners, and the influences on its choice of texts may not be the same as those operating in an established university.

${ }^{25}$ E. Stübler, Geschichte der medizinischen Fakultät der Universität Heidelberg, 1386-1925, Heidelberg, C. Winter Verlag, 1926, pp. 32-41. 


\section{Vivian Nutton}

authors, except in private study. ${ }^{26}$ In 1604 at Freiburg, one modern secured admission to the pantheon of Hippocrates, Galen, Dioscorides, Avicenna, Rhazes, Alexander, Oribasius, Actuarius, and Celsus: significantly it was Fernel, whose reputation, the statutes said, was now unimpeachable. ${ }^{27}$ In 1586 the University of Bologna imposed as the basic texts for surgical lectures only Galen and Galenic anatomy, and this, fortythree years after the publication of the Fabrica. ${ }^{28}$ Indeed, leaving aside Paracelsus and his followers, only in anatomy did the sixteenth century go beyond Galen and Hippocrates in its underlying theories of medicine, and to lay down the classical texts for study and comment might lead to a possibly freer and certainly less invidious system than to prescribe a modern textbook. Indeed, the practical collection of consilia could with justice be regarded as particular applications of a general, humoral, theory of medicine. ${ }^{29}$ They would undoubtedly be useful, but, given the Galenic principles behind them, the humanist physician, ideally, could find them out for himself, although having them to hand might save time and mental energy. Caius' library, it should be noted, contained none of these popular collections, unless the Epistulae medicinales of Manardi are to be counted among them.

The tradition of humanist medicine in England was begun by Linacre, "a man of incomparable learning", ${ }^{30}$ translator of Galen, founder of the College of Physicians, and inspirer of a small group of Oxford scholars in the early 1520s. Of the four names we know, William Rose, Edward Wooton, David Edwardes, and John Clement, Rose, Clement, and, if Dr. Emden is right, Edwardes were involved in the editing and proof-correcting of the great Aldine edition of the Greek Galen, which appeared at Venice in $1525 . .^{31}$ Rose, described by a biographer of Thomas More as "a mad companion that then wandered in Italie, and for the manner of his behaviour was well knowne of most men", is little more than a name, but the other three are of more consequence. $^{32}$ Wooton, appointed public lecturer in Greek at Corpus Christi College,

${ }^{26} \mathrm{G}$. Rath, 'Medical education in the South German Universities in the fifteenth and sixteenth centuries', J. med. education, 1960, 35: 511-517, see p. 515; H. Goerke, in L. Boehm and J. Spörl, Die Ludwig-Maximilians Universität in ihren Fakultäten, Berlin, Duncker \& Humblot, 1972, pp. 189-191; C. D. O'Malley, The history of medical education, Berkeley, University of California Press 1970 , p. 94, giving different dates.

${ }^{27}$ J. Schumacher, Zur Geschichte der medizinischen Fakultät Freiburg i/Br., Stuttgart, Enke Verlag, 1957, p. 18: Fernel is here regarded as modifying certain Galenic doctrines within an overall Galenic, medical framework. Avicenna and Rhazes continued as set texts at Montpellier and Louvain until 1650, and were included in the selected authors in the 1591 statutes of Jena, E. Giese and B. v. Hagen, Geschichte der medizinischen Fakultät der Friedrich-Schiller-Universität Jena, Jena, Fischer Verlag, 1958, p. 17f.

${ }^{28}$ M. Gnudi and J. P. Webster, The life and times of Gaspare Tagliacozzi, New York, Reichner, 1950 , p. 148.

20 The consilia literature would also fit with difficulty into the structure of university teaching, applying, as set texts, only to one part of the Practica of physic.

${ }_{20}$ This was Erasmus' opinion, Adagia 4552, in Opera Omnia, Basle, H. Froben, 1559, p. 965 : this is missing from the list of references to Linacre in Maddison, Pelling, and Webster, op. cit., note 5 above, p. 339-340, as is Cardan's praise of him in his Encomium medicinae (c. 1545), in J. Beverwijck, Epistolicae Quaestiones, Rotterdam, A. Leers, 1644, p. 126.

81 On this edition, N. Mani, 'Die griechische Editio princeps des Galenos (1525), ihre Entstehung and ihre Wirkung', Gesnerus, 1956, 13: 29-52, is fundamental, although, n. 59, following E. Wenkebach, 'John Clement, ein englischer Humanist und Arzt', Stud. Ges. Med., 1925, 14: 11, 14, 51, he identifies the mysterious "Odoardus" with Wooton.

"2 A. B. Emden, A biographical register of the University of Oxford, A.D. 1501 to 1540, Oxford, 


\section{John Caius and the Linacre tradition}

was sent by Bishop Foxe to Padua, where he graduated M.D. in 1525: he was elected in 1528 to the College of Physicians, whose President he was from 1541 to 1543, when he may have been responsible for overseeing the choice of Galenic texts for the fourfold examination. ${ }^{33}$ Edwardes, who preceded Wooton as lecturer in Greek, also studied medicine at Oxford and possibly in Padua in 1524-25, but his importance to us rests on the fact that he wrote the first anatomical textbook in England, although it is little more than a rehash of the standard Italian anatomy text of Mondino dei Luzzi: he probably was also the first in this country to carry out public dissections, although whether in Oxford or in Cambridge, whither he migrated in 1528-29, is uncertain. ${ }^{34}$ But the most important, beyond doubt, was John Clement, friend and pupil of Thomas More, Royal Physician, President of the College of Physicians in 1544, and later a distinguished Marian exile at Louvain. Although his published writings concern theology, not medicine, his medical ideas and achievements, thanks to Ernst Wenkebach, are adequately known, and the recent publication of Merton documents has emphasized his close relationship with Linacre. ${ }^{35}$ Clement was the first of the Corpus Greek lecturers, in 1518, a post he gave up to go and study medicine at Padua. While there, he played a major role in the publication of the Aldine Galen, being responsible for the final draft of many treatises sent to the printer and making many excellent emendations to the text. ${ }^{36} \mathrm{He}$ also had manuscripts of Galen copied for him in Venice, which he subsequently lent or bequeathed to others. One which he left to Corpus is now, for reasons unknown, in Paris, ${ }^{37}$ and he provided Caius with manuscripts of Anatomical procedures and On the preservation of health, and with the curious tale of the mutilated Aldine text of On gruel; the head printer nodded off, letting the candle fall on his exemplar and burn parts of $1{ }^{38}{ }^{38}$ In return for Clement's generosity to him, Caius loaned him a Greek manuscript of Dionysius the Areopagite for use in his theological studies. ${ }^{39}$

There may have been others in Oxford and Cambridge in the same tradition of humanist medicine: Thomas Symons, fellow of Merton, who died in 1553;00 or George Day, Linacre lecturer at St. John's College, Cambridge, later bishop of

Clarendon Press, 1974, p. 492: Wenkebach, (op. cit., note 31 above, p.57) identified him with Antony Rose, friend of John Leland.

2s Emden, op. cit., note 32 above, p. 639: on his merits as a naturalist, C. E. Raven, English naturalists from Neckam to Ray, Cambridge University Press, 1947, pp. 40-42.

34 Emden, op. cit., note 32 above, p. 185; David Edwardes, Introduction to anatomy, edited and translated by K. F. Russell and C. D. O’Malley, Oxford University Press, 1961.

${ }^{26}$ Wenkebach, op. cit., note 31 above; J. K. McConica, English humanists and Reformation politics, Oxford, Clarendon Press, 1965, pp. 269-272; J. M. Fletcher, 'Linacre's lands and lectureships', in Maddison, Pelling, and Webster, op. cit., note 5 above, pp. 107-197, see pp. 125-127, 148-150, 190-193.

* Wenkebach, op. cit., note 31 above, pp. 14-17, 53-58; Mani, op. cit., note 31 above, p. $41 f$.

27 Paris, Bibliothèque Nationale, fonds grec, 2168; Wenkebach, op. cit., note 31 above, p. 54.

${ }^{38}$ De libris propriis, pp. 77, 83, 90: "the man then in charge of the Aldine press"' should be Asolano, not Oppizzoni, as O'Malley thought, English medical humanists, Lawrence, University of Kansas Press, 1965, p. 52.

" Grierson, op. cit., note 19 above, no. 122: Caius' veneration for Clement is obvious from his writings: in his marginalia (below, p. 386), fol. 4v, he calls him "egregius medicus ut si quis alius totius Europae". Bullein, op. cit., note 4 above, p. iiiiv, includes Clement alongside Linacre and Caius in his list of distinguished surgeons.

to Emden, op. cit., note 32 above, p. 739. 


\section{Vivian Nutton}

Chichester, and a man, according to Caius, "long enthusiastic over medicine and entranced by its precepts", are but two possibilities, ${ }^{41}$ but it is John Caius who stands out as the most celebrated and influential. The discoverer, editor, and translator of Galenic treatises, the author and reviser of statutes of the College of Physicians which imposed a knowledge of Galen as the qualification for membership, who in 1559 and 1560 was instrumental in forcing the unlucky Dr. Geynes to confess his ignorance in attempting to convict Galen of error, and who preferred to follow a tall story recorded by Julius Caesar about the elk rather than the evidence of contemporaries who had seen the animal; all this reveals a man deeply embedded in the classical tradition. ${ }^{42}$ The catalogue of his library confirms this stance. It contains five copies of Hippocrates or his commentators, five of Dioscorides, four of Celsus, two of Alexander, two of Paul, one each of Aretaeus, Aetius, Avicenna's Canon, and Rhazes' minor works, together with seven partial or complete printed editions and six manuscripts of Galen, in all, thirty-four classical books or manuscripts and two Arabic. By comparison, the moderns are a bit thin, twelve volumes in all, of which only one, Dupuis' On the property of purgatives, was first printed after 1550, and only one, Vesalius' Fabrica, could be regarded as non-Galenic although still in the humanist tradition. Apart from Gesner's History of animals and tract on fossils, and two books by Pierre Belon, his other scientific volumes are similarly old-fashioned: his encyclopaedia, Reisch's Margarita philosophica, was decidedly antiquated, having appeared first in $1503 .{ }^{43}$ The contrast between this library and those of Roger Gifford, Linacre lecturer at Merton in 1561 and later President of the College of Physicians, or Thomas Lorkyn, Regius Professor of Physic at Cambridge from 1564 to 1591, is not just a contrast between two generations, to be explained by the intervening

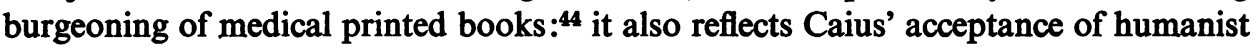
doctrines at a time when such a belief in the unique virtues of classical authorities was neither unusual nor unjustifiable. ${ }^{45}$

With the partial exception of anatomy, whose immediate effect on the treatment of the sick was small, it was not until the Paracelsian revival on the continent in the late

41 J. Caius, Opera aliquot, p. 235, with R. G. Lewis, 'The Linacre lectureships subsequent to their foundation', in Maddison, Pelling, and Webster, op. cit., note 5 above, p. 228.

12 Caius, Annales Collegii Medicorum, pp. 51, 53f.; De rariorum animalium historia, p. 39, with Raven, op. cit., note 33 above, p. 142.

${ }^{43}$ Grierson, op. cit., note 19 above, p. 522. One area in which his library list seems to show no interest is alchemy and the occult, but Dr. Webster informs me that the British Library Add. MS. 36,674, fols. 5-63, contains notes from Agrippa von Nettesheim and miscellaneous conjurations, and is said to derive from Caius via his successor as Master, Thomas Legge.

" Lewis, op. cit., note 41 above, p. 236; C. Sayle, 'The library of Thomas Lorkyn', Ann. med. Hist., 1921, 3: 310-323.

${ }^{15}$ Caius' library list is similar to that of Henry Walker, Lorkyn's predecessor as Regius Professor, d. 1564 (J. Venn (editor), The annals of Gonville and Caius College, Cambridge University Press, 1904, p. 119), John Dotyn, fellow of Exeter College (Emden, op. cit., note 32 above, p. 719 f.), and of Robert Barnes, Linacre lecturer at Merton from 1558 to 1604 (ibid., p. 714 f.; Lewis, op. cit., note 41 above, p. 233), who seems, like Caius, to have acquired few new books in his later years. To emphasize the contrast is also to read into sixteenth-century medicine our own expectations of progress and of a willingness to change, like Leoniceno (whose later Galenism led him to reject many of the scholastic fashions of his youth) and Guinther (who eventually became a Paracelsian). Caius' principles were largely formed by the 1540 s, and he may well have regarded modern works as particular instances of those principles, which he could discover easily for himself. 


\section{John Caius and the Linacre tradition}

1560s that Galenic medical theories were seriously challenged: they might be refinedfor not even Galen had dealt with every possible point-but they were not largely rejected. In therapy, it was widely believed that, provided one had a thorough knowledge of Galenic general principles (which was only to be gained by years of careful and concentrated study at a university), particular treatment could be easily decided upon.

A boke or counseill against the sweate, while of more than passing interest for being compiled by Caius in the vernacular from his own observations in Shrewsbury and elsewhere, is written upon the best of Galenic theories and to a medieval plan based on the six non-naturals. ${ }^{46}$ The cause of the disease, first the, external, infection of the air and second the, internal, corruption of the body by repletion, can be avoided by keeping away from impure air and by appropriate diet, and cured by rest and by keeping the patient in a warm, but not unhealthy sweat, thereby assisting nature in nature's way; all this comes from Galen, although whether he would have approved of Caius' sententious and antiquarian moralizing is open to doubt. ${ }^{47}$ Those most liable to die of the sweat were those who drank good English ale or beer as a universal remedy, and Caius attributed in part the decline of England's "olde manly hardnes, stoute courage \& peinfulnes" to a delicate taste for hot buttered toast. ${ }^{48}$

His Method of medicine, which he regarded highly, has not attracted as much interest as the Counseill, partly because it contributes, apparently, little of whiggish progress, but for its own day it served a valuable purpose in presenting in accessible form the latest developments in a philosophical and medical debate that had been going on for centuries in Padua. It is a juvenile work, a mere elegant summary of the theories of Caius' teacher, G. B. Da Monte (Montanus), yet modern disapproval of what we see as plagiarism should not blind us to the practical value of its contents. Caius candidly admitted his borrowing, but correctly emphasized the importance of the publicist in spreading the new and up-to-date therapeutic method: if it was clear and effective, it was all the more essential to fix it in print and to secure for it as wide a readership as possible.49

Da Monte represented a tradition of Padovan medicine to which Caius adhered

46 Such an arrangement was standard in the late medieval period for consilia, plague tractates, and the like (cf., D. P. Lockwood, Ugo Benzi, Chicago, University of Chicago Press, 1951, pp. 4758), and, as such, would be easily intelligible to Caius' contemporaries. Although deriving ultimately from Galen, the theory of the non-naturals was expressed most clearly in the basic university medical text, Johannitius' Introduction: in that part of the tract (in both English and Latin) which concerns prophylaxis, the order is: food and drink (p. 20 E.; p. 88 L.); air (p. 22 E.; p. 95 L.); inanition and repletion (p. 24 E.; p. 99L.); exercise (p. 27 E.; p. 102 L.), including sexual intercourse (p. 28 E.; p. 103 L.); sleep and waking (p. 29 E.; p. 103 L.); mental afflictions (p. 29 E.; p. 104 L.).

47 The purpose of the tract was, on the one hand, to provide a remedy on the most up-to-date continental lines by an English doctor to a specifically English disease, and, on the other, to show the relevance and value of new Galenic learning in medical practice. For recent work on the English sweat, see R. S. Roberts, 'A consideration of the nature of the English sweating sickness', Med. Hist., 1965, 9: 385-389; R. S. Gottfried, 'Population, plague and the sweating sickness; demographic movements in late fifteenth-century England', J. Br. Stud., 1977, 17: 12-37.

18 Counseill, pp. 19, 21; cf., De ephemera Britannica, pp. 83, 90, for a rephrasing and expansion of the former sentiment.

40 This confession comes only later, in De libris propriis, pp. 73-75. My understanding of the significance of Caius' Method owes much to discussion with Andrew Cunningham, who is preparing a wider study of method in the sixteenth and seventeenth centuries. 


\section{Vivian Nutton}

and which has been almost forgotten in the concentration of effort on the history of Renaissance anatomy. He was a Galenist and a specialist in therapeutics. At Padua, where he held chairs in both theoretical and practical medicine, he instituted visits with his students to the hospital of S. Francesco and even to the homes of the sick, and discussed cases with them at the bedside, believing that they would gain more from the practical experience of viewing disease than from a mere reading of textbooks. His lectures dealt with pharmacology, fevers, and urines, and were often in the form of commentaries on the standard practical texts of the curriculum, the Aphorisms, Galen's Art of medicine, Avicenna's Canon, and Rhazes' Book nine, for Al-Mansor. ${ }^{50}$ Especially in his lectures on the Art of medicine and the Method of healing, for Glaucon, he continued a Paduan tradition of investigation and exposition of the intellectual bases of medical practice, combining the older views of Pietro d'Abano with the new insights of Niccold Leoniceno and the recently published tract of Galen, the Therapeutic method. ${ }^{51}$ This emphasis on method, "without which the doctor would find himself in many a blind alley," was one of the major rediscoveries of Renaissance humanist medicine. ${ }^{52}$ No longer had physicians to manage with an interpretation of Galen's therapy solely in terms either of scholastic philosophy or, following Leoniceno, of his "tres doctrinae" as models of formal instruction. Now they had a guide to therapy at once subtle and practical, which combined philosophy, logic, and medicine in a way that suited their own needs.

But Da Monte, like many of his contemporaries, was unwilling to release his lecture notes for publication immediately, and left to his students the task of promulgating his ideas to the world at large. ${ }^{53}$ His lecture notes were, for the most part, published by his northern admirers only after his death in 1551, although some of them had been composed several years previously. His Universal method of healing, for so it is called in the Basle edition of 1558, was in effect his lectures on Galen's Therapeutic method, for Glaucon, and had been produced in Venice in 1554 by Walenty Lublin in a slightly different form as Commentary on Galen's books on the art of

\footnotetext{
so O'Malley, op. cit., note 18 above, p. 430, gives a brief biography and bibliography; to which add, as well as the works on method listed in the following note, R. J. Durling, $A$ catalogue of sixteenth-century printed books in the National Library of Medicine, Bethesda, Md., National Library of Medicine, 1967, pp. 414-418. Da Monte also supervised the first Juntine edition of the Latin Galen, Venice, 1541-42, although he does not appear to have made any Galenic versions himself.

s1 The earlier, philosophical, Paduan debate is described in J. H. Randall, jr., The school of Padua and the emergence of modern science, Padua, Antenore, 1961; N. W. Gilbert, Renaissance concepts of method, New York, Columbia University Press, 1960, esp. pp. 13-24, 98-107; W. F. Edwards, 'Niccolo Leoniceno and the origins of humanist discussions of method', in E. P. Mahony (editor), Philosophy and Humanism, Leiden, Brill, 1976, pp. 283-305. For its medical significance, see W. P. D. Wightman, Science and the Renaissance, Edinburgh and New York, Oliver \& Boyd, 1962, pp. 207225; 'Quid sit methodus? Method in sixteenth century medical teaching and discovery', J. Hist. Med., 1964, 19: 360-376; 'Les problèmes de méthode dans l'enseignement médical à Padoue et à Ferrare', VIIIe Congres Int. de Tours, Sciences de la Renaissance, Paris, J. Vrin, 1973, 187-195.

52 J. B. Montanus, Opuscula varia, Basle, Perna, 1558, vol. 1, p. 5 f.; Galen's Therapeutic method was first printed in Greek in 1500, Venice, Z. Callierges for N. Blastos, from one of Leoniceno's manuscripts, and the standard humanist Latin version was that of Linacre, Paris, 1519, D. Matheu for G. Hittorp, and twenty-seven times reprinted before 1600. It replaced the translations of Gerard of Cremona (from the Arabic) and of Burgundio of Pisa (from the Greek, but of only the last six books).

s3 Cf. M. Colombo's preface to his publication of H. Mercurialis, De morbis muliebribus, Venice, Giunta, 1587.
} 


\section{John Caius and the Linacre tradition}

healing, for Glaucon. A brief account of its major theses, edited by J. von Schröter, had appeared four years before, in Vienna under the title The idea and characteristics of Hippocratic doctrine, ${ }^{54}$ but Caius' more substantial exposition had come out considerably earlier, in 1544. Even if later authors found Caius' digest of Da Monte's teaching only "moderately well expounded"-Crato's justification for his Therapeutic method according to the opinion of Galen and G. B. Da Monte ${ }^{55}$-this should not deny him the credit for being the first to make generally available to all doctors the most modern ideas of medical therapy and rules for general practice, deriving from a Paduan meditation on Galenic medicine. The influence of such books on method should not be minimized simply because their basis has been overthrown: for well over a century they were a staple guide to medical practice, and confirmed $\mathrm{Da}$ Monte's belief that method was more than a theory, it was a philosophical understanding translated into action. ${ }^{56}$ In his choice of therapeutic ideals Caius was as much in the forefront of his time as was Vesalius in anatomy, and, he could argue, was of more immediate benefit to the sick.

The leading teachers of medicine in Caius' lifetime, and for many years beyond, were as committed Galenists as he. Antonius Musa Brasavola, professor at Ferrara, carried out researches into pharmacology and compiled what is still today the best index to the works of Galen; ${ }^{57}$ Conrad Gesner, naturalist and friend of Caius, edited the complete Latin Galen and composed the first scholarly bio-bibliography of his writings ${ }^{58}$ Hieronymus Mercurialis, professor at Padua, Bologna, and Pisa, wrote his most famous work, On the art of gymnastic, as an avowed attempt to restore classical methods of exercise to general therapy by purifying them of any taint of pagan immorality. ${ }^{59}$ All these adherents of classical medicine have been praised by whig historians for the new developments they instituted or foreshadowed, yet they were as much bound to their ancient sources as Caius. The treatise of Mercurialis most printed in his lifetime was not his book on gymnastic or his classifications of diseases, but his series of notes, emendations, and explications of classical authors, his Variarum lectionum libri. ${ }^{60}$

54 On Schröter (1513-1593), first Rector of the University of Jena and a student at Padua from 1549-51, see Giese and v. Hagen, op. cit., note 27 above, pp. 47-65: Zeitz, Stiftsbibliothek 66, is a Greek MS. that he bought (and had copied for him?) in N. Italy, see C. Wendel, 'Die griechische Handschriften der Provinz Sächsen', in G. Leyh (editor), Aufsätze Fritz Milkau gewidmet, Leipzig, Teubner, 1921, pp. 368-372.

${ }_{85} \mathrm{~J}$. Crato von Krafftheim, Methodus therapeutica ex sententia Galenii et Joannis Baptistae Montani, in Montanus, Opuscula varia, op. cit., note 52, above, vol. 2, p. 242.

se On the importance of method in sixteenth- and seventeenth-century medicine, see D. G. Bates, 'Sydenham and the medical meaning of method', Bull. Hist. Med., 1977, 51 : 324-338.

${ }^{67}$ Thorndike, op. cit., note 7 above, vol. 5, pp. 445-471; G. Gliozzi, Dizionario biografico degli Italiani, 1972, vol. 4, p. 51 f.; De libris propriis, p. 102,

${ }^{68}$ H. Fischer (editor), Conrad Gesner, 1516-1565, Zürich, Leeman A. G., 1965; H. Wellisch, 'C. Gesner, a biobibliography', J. Soc. Bibliog. nat. Hist., 1975, 7: 151-247; Caius' eulogy for his dead friend is particularly informative for his conception of their shared ideals, De libriis propriis, pp. 94-98.

${ }^{50}$ Christine Nutton, Hieronymus Mercurialis, De arte gymnastica: an introduction, Stuttgart, Medicina Rara, 1978, pp. 10-12.

${ }^{60}$ There were at least six printings of this, first in four books, Venice, Perchacinus, 1570; then in five, Basle, Perna, 1578; then in six, Paris, Nivelle, 1585, with additions to the last book made in 1588 and 1598. 


\section{Vivian Nutton}

Caius' Galenism was thus in no way unusual, and indeed his arguments in defence of Galen are saner than those of Jacobus Sylvius and those anatomists who believed that man had degenerated since Galen's time and thus that his anatomical descriptions were accurate reproductions of a bygone race. ${ }^{61}$ Caius preferred a more scholarly, a more philological approach. In his view, Galen's omissions did not indicate his ignorance, but his contempt for minutiae: given the magnitude of his achievement, the production unaided of a whole system of medicine, it was not surprising that he could not include everything: rather, he should be praised for concentrating upon essentials. ${ }^{62}$ Besides, some so-called errors were the result of misunderstanding or mistranslation: his enumeration of the muscles depended on his definition of the form and function of a muscle, and could not be contradicted by those, like Vesalius, who relied merely upon the similar visible shape of some fibres. ${ }^{63}$ Nor did Galen believe in the multiple lobes of the liver: that was a faulty translation, which confused "lobes" with the ridged fibres which stand out on the surface of the liver. ${ }^{64}$ A combination of a more accurate text, made from better manuscripts, and a more faithful translation would, he was convinced, show the impeccability of Galen and the rash emendations of Vesalius, who corrupted the text of Anatomical procedures to give the sense he wanted. In this Caius was not always wrong. In the revised Fabrica of 1555 Vesalius included a new drawing of the ginglymus hinge to replace one cogently criticized by Caius in his notes to his edition of Anatomical procedures. ${ }^{65}$ In his estimate of the poor quality and slender manuscript base of the 1525 Aldine edition he was neither alone nor incorrect. That judicious critic Erasmus had early voiced his disappointments at its errors and misprints, ${ }^{66}$ and, contrary to its publishers' protestations, it rested on a handful of generally poor codices from Venice and its environs. ${ }^{67}$ Caius' hunt for manuscripts in Italy and elsewhere was one way of rectifying the errors of the standard edition, but as we can now see, major errors of substance in the manuscripts are few, minor deviations many, and the Galenic texts recovered since Caius' day have only confirmed Galen's fallibility. Yet at a time when much was still unknown and rested, apparently, on a tenous manuscript basis, Caius' method of defence was not ill-advised, and, in the context of the 1540s and 1550s, more restrained and sober than some. If to us the weaknesses of this philological approach are only too clear, this was not the case in Caius' lifetime, and he should not be criticized strongly for backing the wrong horse. At least, he was an

$61 \mathrm{~J}$. Sylvius, Vaesani cuiusdam calumniarum in Hippocratis Galenique rem anatomicam depulsio, Paris, Barbé, 1551, fols. 7v-8v. On Caius' friendship with Vesalius' opponents, cf. De libris propriis, pp. 86, 102 (Corti), 103 (Drivière); and M. F. Ashley-Montagu, 'Vesalius and the Galenists', in E. A. Underwood (editor), Medicine, science and history, Oxford University Press, 1953, vol. 1, pp. 374-385.

${ }^{62}$ De libris propriis, p. 81; this contrasts with the standard charge against Galen of being longwinded, e.g. G. L. Kustas, Studies in Byzantine Rhetoric, Thessalonica, 1973, pp. 111, 113, 191.

6s De libris propriis, pp. 77-80; cf. the argument of Galen in On the opinions of Hippocrates and Plato, C[orpus] M[edicorum] G[raecorum], V. 4. 1. 2, p. 92 f. = Galeni libri aliquot, p. 12.

De libris propriis, p. 82.

${ }^{65}$ Galeni libri aliquot, p. 299: De libris propriis, p. 82: O'Malley, op. cit., note 18 above, p. 274.

${ }^{66}$ Erasmus, Epistulae, edited by Allen, 2049, 1526, 1707 (to G. B. Egnazio, for whom see De libris propriis, p. 102); cf. also Durling, op. cit., note 14 above, p. 237, n. 37.

$67 \mathrm{Mani}$, op. cit., note 31 above, note 62, deals with the MSS., but more work is still needed. Pace Asolano's preface, I, fol. 1r, which talks of searching Italy for MSS., those in Florence were certainly not used, although they were available for inspection. 


\section{John Caius and the Linacre tradition}

honest punter, unlike his Venetian contemporary, the editor and translator of Galen, G. B. Rasario, whose zeal and ingenuity led him to fabricate Galenic commentaries which still entrap the unwary. ${ }^{68}$

Let us rather meet Caius on his chosen ground, as a textual critic of Galen and as a humanist physician, a task which has been avoided by all Caius' biographers, yet one which enables us to make a fair assessment of his place among those of his contemporaries who shared in that tradition of humanist medicine. First, his positive contributions. He made available for study more writings of Galen than any editor since the Aldine team: the Greek version of On coma and On the seven-month child, substantial parts of On the opinions of Hippocrates and Plato, On the use of parts, On substitute drugs, and On gruel, and the first Latin translation of the Commentary on Hippocrates' On diet in acute disease, although this is now recognized as a medieval forgery. ${ }^{69}$ Yet the new texts are perhaps not as impressive as his revision of older translations and published editions.

To this end, he collated manuscripts, listed the libraries where they might be found, and had copies made for his own use. Five of the six manuscripts of Galen that he left to his College were written for him in Florence, Venice, and Paris, and the other, Gonville and Caius, MS. 47/24, was obtained in 1543 in Italy in circumstances obscure and perhaps discreditable. It is composed of various older fragments, including, section III, fols. 1-9, those portions of On the opinions of Hippocrates and Plato which he was the first to edit. These leaves are none other than the first quaternion and a leaf of the third from a codex (Laurentian 74.22) in the Medicean Library in Florence, where Caius studied. ${ }^{70}$ As Professor De Lacy has shown, the mutilation of the Florentine manuscript took place between 1525 and 1543. Did Caius, like some sixteenth-century Tischendorf, tear out the pages himself while the librarian was not looking, or was he the unwitting victim of an unscrupulous dealer in antiquarian books?

In his emphasis on manuscripts for their contributions to the text, Caius is continuing the tradition of Linacre, Leoniceno, and the early medical humanists, ${ }^{71}$ and in this he was not unique among his contemporaries. Clement, George Owen, and Matteo Corti owned Greek medical manuscripts: ${ }^{72}$ the Pole, Josef Struš, emphasized his own struggles to secure a "most ancient manuscript" for his edition of Galen's Prognostics: ${ }^{73}$ and Rasario, in preparation for his edition of Galen's commentaries

o8 Caius thought highly of him, De libris propriis, p. 94: but see E. Wenkebach, C. M. G. V. 10. 1 (1934) pp. XXVIII and XXXIII, and V. 10. 2. 2. (1956), p. XXIV (for his forgeries of Galen's commentaries on Epidemics II and VI (books 6 to 8); for those of the commentaries on Humours, K. Deichgräber, 'De Humoribus in der Geschichte der griechischen Medizin', Abh. Akad. Mainz, Geistes- u. soz. Kl., 1972, p. 45 [715]; and for the commentaries on Diet, the note by H. Diels, Sber. Preuss. Akad., 1914, p. 128, without specifically inculpating Rasario, their first translator.

69 For Caius' estimate of his own achievements, as a discoverer and publisher of new texts. De libris propriis, pp. 75f., 83, 85, 89f., $107 \mathrm{f}$.

${ }^{70}$ I. v. Müller, Claudii Galeni De placitis Hippocratis et Platonis libri novem, Leipzig, Teubner, 1874, vol. 1, pp. 42-45, 73-74; P. De Lacy, Galeni De placitis Hippocratis et Platonis, C. M. G. V. 4. 1. 2, (1978), p. 31, although his reason for saying it was bought at Paris is unclear.

"1 Cf. Bonardus' claim, Galeni opera omnia, Venice, P. Pincius, 1490, fol. 1v, to have looked for Latin MSS. of Galen 'in quamplurimis Italie gimnasiis'.

12 De libris propriis, pp. 77, 83, 102.

Galeni Prognostica de decubitu, Venice, Padoano \& Ruffinelli, 1535. 


\section{Vivian Nutton}

on the Epidemics, borrowed at least one codex from the Marcian Library in Venice. ${ }^{74}$ But two things may distinguish Caius from these scholars: his use of detailed collations of manuscripts (although little is known of others' working methods) and, second, the extent of his investigations.

His own copy of his 1544 editions of Galen, now in the Cambridge University Library, Adv. d. 3,1, is eloquent on his methods. It contains, in preparation for a projected second edition of Anatomical procedures, a detailed collation of one manuscript, called C 2, and as yet unidentified, giving good readings as well as bad, and even noting changes of punctuation. There are no such annotations from p. 116,16 to p. 148,24, where the collations begin again with a reference to "cod. Cle(mentis)", which I consider is the same as C $2 .{ }^{75}$ In the last two books, although the detailed collations continue, no abbreviation is used to mark their origin. Caius also refers from time to time to a "cod. Linacri", ending at p. $117,6=\mathrm{II}$, p. $419,1 \mathrm{~K}$. with the note, "Thus far Linacre's manuscript". ${ }^{76}$ There can be no doubt that this is the manuscript once owned by Linacre and now in the University Library at Leiden, MS. Vulcaniani 57, which breaks off at this point, ${ }^{77}$ and it confirms Caius' statement, De libris propriis, p. 77, that he used copies found in England and owned by Linacre and Clement in preparation for a never-published revised edition. There is a possible third manuscript mentioned at p. 17, a "cod. Ges(neri)", but, from Caius' habit of also calling printed books "codices", this reference could be to a printed work of Gesner or even to his Latin edition of Galen, Lyons, J. Frellon 1549-1551. ${ }^{78}$ Similar, although incomplete, collations can be found in the margin and text of On the opinions of Hippocrates and Plato, and, printed as an appendix on pp. 90-91 of his edition of On the use of parts, variant readings from two manuscripts, one "very ancient, the other recent". ${ }^{79}$

What his purpose was in making these detailed lists, even of errors (a very rare practice in the Renaissance ${ }^{80}$ ) is clear from his opening note on Anatomical procedures, p. 281, and from the, now truncated, comment he added in the margin. His notes were intended to show what had been achieved and why, and the collations were first to help in identifying a new manuscript and, second, to provide a stimulus to the consideration of manuscript errors and to the formulation of appropriate emenda-

7 H. Omont, 'Deux régistres de prêts des manuscrits de la bibliothèque de Saint-Marc à Venise', Bibliothèque de l'Ecole de Chartes, 1887, 48: 680; cf. C. M. G. V. 10. 2. 2. (1956), p. XXIV, n. 5.

${ }^{75}$ Fol. 17,20 refers to "nostrum exemplar Ioannis Clementis", and fol. 234 to "liber vetus doctiss. Ioannis Clementis qui occasionem dedit emendandi".

${ }^{70}$ Other references to Linacre's manuscript are given in the notes on pp. 301, and 331; Caius appears only to have checked this copy from time to time and not made a complete collation as for C 2.

${ }^{7} \mathrm{G}$. Barber, in Maddison, Pelling, and Webster, op. cit., note 5 above, p. 334.

${ }^{78}$ He refers to the Aldine edition as a codex, p. 282, and to the Basle edition as "cod. Germa.", p. $293 \mathrm{f}$.

79 One of these is to be identified with his own manuscript, Gonville and Caius MS. 47/24: G. Helmreich, Galeni De usu partium, Leipzig, Teubner, 1907, p. X, fails to refer to these collations and says that Caius based his edition on a (single) unknown codex.

${ }^{80}$ Kenney, op. cit., note 9 above, pp. 51, 60, and, on Politian, an important exception, pp. 7-10, and cf. Caius, De libris propriis, p. 87 (on Laur. Plut. 75.8), who misread Politian's date of 1487. J. J. Scaliger's notes in his Aldine edition, now in Wolfenbüttel, are similar, although a generation later, collations of Galenic manuscripts in N. Italy, see V. Nutton, C. M. G. V. 8. 1 (1979), p. 45 f. 


\section{John Caius and the Linacre tradition}

tions. He is scrupulous in distinguishing in his marginalia his conjectures (castigationes) from variant readings, and, in his revision of the notes, often strengthens his comments by referring to the greatest number of manuscript witnesses in favour of this or that reading. Modern rules of stemmatics and textual criticism were, of course, unknown to Caus, but his decision in On the use of parts, p. 99, to follow in general his older manuscript, but not to neglect the younger, seems eminently sensible. How far he rigorously carried out this decision in practice is, alas, impossible to say.

The extent of his travels in search of manuscripts is also impressive, and reminiscent of an earlier generation of humanists. His older contemporary, Manardi, might bewail the fact that in the 1530s all Galenic manuscripts "flowed as if from one fount" (i.e., Venice) but he made no attempt to seek other springs. ${ }^{81}$ By contrast Caius spent almost a year looking in Italy and elsewhere for new manuscripts to use in future editions, and several of them can be identified. He based his edition of On the preservation of health on the Aldine edition, Linacre's Latin version, and on copies of two Venetian MSS., Marcian 276, an excellent codex that had been written for Cardinal Bessarion, and Vatican, Reginensis 173 , formerly the property of Gioacchimo della Torre, some-time head of the Dominicans of SS. Giovanni e Paolo. ${ }^{82}$ Florence, Laurentian 74.3, supplied him with the Greek text of On coma and On diet in acute diseases, but for the latter he does not seem to have used a Marcian MS., then at SS. Giovanni e Paolo. ${ }^{83}$ Perhaps more interestingly, his fine translations of On $m y$ own books and On the order of my own books was based on a codex, now lost, from the Laurentian library: ${ }^{84}$ because in these two tracts Caius' translation is far superior to his usual standard, and his emendations more acute, it is likely that his MS. was of a greater worth than the sole Greek MS. of the tracts surviving today, Milan, Ambrosian Q. 3. sup.

But his eager search for old manuscripts, while valuable in itself, may have blinded him to the value of earlier translations. He speaks with affection of his fellow humanists, Machel, Rasario, Linacre, and Camerarius, and of the honest rivalry between Antonio Giunta, Agostino Ricci, and Vittore Trincavelli to produce the most elegant and correct Latin Galen, but of his medieval predecessors there is not a word. ${ }^{85}$ Thus in bringing to light in 1544 Galen's little book on coma, he diligently indicates the gaps in his manuscript exemplar, but he does not appear to know that a Latin version by Niccold da Reggio, containing many of the missing bits in a wordfor-word translation from the Greek, had already been printed in the 1490, 1516, and 1528 editions of the Latin Galen. Ricci, who was a shrewder scholar than Caius, did not miss this opportunity to improve the text, for in his Latin version of 1541 he relied not only on a revised Greek text but filled in the gaps by a judicious use of

81 Epistularum medicinalium libri XX (19.5).

${ }^{82}$ K. Koch, C. M. G. V. 4. 2 (1913), p. XIV: Gonville and Caius, MS. 77/44, includes marginal collations made by Caius from another MS. formerly owned by Della Torre.

a J. Mewaldt, C. M. G. V. 9. 2 (1915), p. XV: J. Westenberger, C. M. G. V. 9. 1. (1913), p. XLII. For Caius' use of the library at SS. Giovanni e Paolo, see De libris propriis, p. 100, and the previous note.

s De libris propriis, p. 101: it was unfortunate that the last editor of these tracts, I. v. Müller, Scripta Minord Galeni, Leipzig, Teubner, 1891, vol. 2, seems not to have known of this.

es De libris propriis, pp. 94, 102, 76. 


\section{Vivian Nutton}

Niccolò's work. Of all this, Caius in 1544 makes no mention. ${ }^{86}$

Caius deserves praise for his diligent search for manuscripts in public and private libraries, and for bringing their contents once more into the light, but how do his abilities as editor and translator compare with those of his fellow medical humanists? Here an answer must be impressionistic, for, apart from Durling's masterly study of Linacre's translation-technique, nothing has been done on these Renaissance scholars, whose talents, if one were to believe their prefaces, were considerable in their own eyes, ludicrous in their opponents'. Caius' performance rates a solid second: his transcriptions are generally accurate, but the known manuscripts from which he copied are all clearly legible and written in an easy hand. His technique as translator, while more elegant than that of Cop or Guinther, is not as idiomatic as that of Linacre or Rota, and is marred by his desire to defend Galen by making an unusual translation if need be. His second thoughts and corrections in the Cambridge copy of his 1544 versions show how much better he could, on reflection, have done. ${ }^{87}$

As for his changes to the Greek text, they derive largely from the readings of the new manuscripts he discovered, and their merit rests on that of the manuscripts. For example, in On the preservation of health, where Caius had good manuscripts, a modern editor accepts some 150 of his "emendations": ${ }^{88}$ on the other hand, in On gruel, where his exemplar was akin to the source of the Aldine and Basle editions, his contributions are negligible. ${ }^{89}$ So, when I find in his version of Galen's catalogues emendations which are made otherwise only by Cornarius or modern scholars, I conclude that they come not from Caius' own genius, but from his lost Florentine codex. I give two examples of felicitous changes: $\mathbf{0}^{90}$

p. 240,1 Caius=II, p. 93,26 Müller: "in that (book)" Caius, Cornarius, Helmreich: "in that (art)" edd.

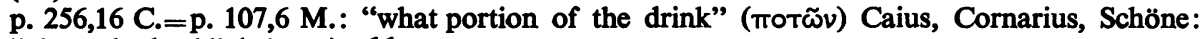
"along the back" ( $\nu \omega t \omega v)$ edd.

In his knowledge of Greek and his flair for textual criticism, he is only moderately endowed. His strength lies in his memory and his ability to provide supporting references or parallel passages to illustrate Galen's use of a word or illuminate its meaning; and his annotations, both published and marginal, are of help in this way to a modern

${ }^{86}$ Ibid., p. 89. In Galeni libri aliquot ...., sig. 3v, he alleges that Diego Mendoza, the ambassador of the Holy Roman Emperor to Venice, had searched for previous editions at his request: he himself calls it a work "never before discovered or printed".

${ }^{87}$ For example, he deletes the note, p. 334 , to the text of p. 268,28 , and the wrong translation,

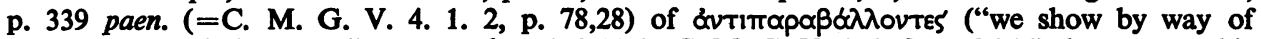
contrast") as "simile ostendimus"; and, p. 352,11 (=C. M. G. V. 4. 1. 2, p. 96,14), he corrects his version of oukkpov ("small") from "Vnum tantum" to "exiguum quidem". Many of the corrections made in the margin of the translation of On the opinions of Hippocrates and Plato were incorporated in his re-edition in the Opera aliquot of 1556.

${ }^{88}$ K. Koch, C. M. G. V. 4. 2 (1913), pp. XIV, XXIV f.

80 O. Hartlich, ibid., p. LXII.

${ }^{\circ}$ Other notable changes are: additions at p. 256,9 C. $=$ p. 107,3 M.; p. 277,12 ff. C. $=$ p. 122,20 M. (both made also by Müller); the addition at p. 260,13 C. $=$ p. 110,11 M. of kal Tò $\pi \varepsilon p l \sigma \varphi \zeta \gamma \mu \tilde{\omega} \nu$

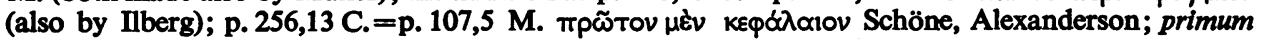

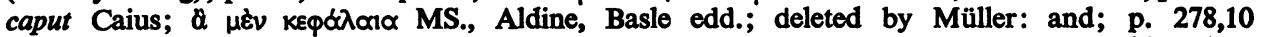
C. $=$ p. 123,10 M. $\phi i \lambda \circ \sigma \circ \phi i \alpha v$ Cornarius, Schöne; philosophiam Caius; $\phi 1 \lambda \circ \sigma \delta \phi \omega \nu$ MS., edd. 


\section{John Caius and the Linacre tradition}

editor. ${ }^{91}$ But he has no special gifts or nose for the unusual, like Cratander and Gemusaeus, the editors of the Basle Galen, or Ricci, ${ }^{22}$ and, when compared with Janus Cornarius, he is far inferior in the number, variety, and range of his conjectures. ${ }^{93}$ This assessment, if it were based only on their printed works, might appear harsh, for Cornarius' versions, while perhaps more stylish, are equally disappointing in the improvements they bring to the text. But a glance at their marginalia confirms that the gulf between them is great. Cornarius, by his own genius, corrects his Aldine with a sure touch and a sensitivity to the Greek: Caius' conjectures, once away from any manuscript, are often wild, hispid, and ungrammatical, bludgeoning the text into submission and caring little for subtlety or elegance. ${ }^{94}$

Caius lacks that divinatory spark, the originality that would proclaim him a genius: he is predictable, honest, and enthusiastic in following the ways laid down by others, the ways of conservative classicism. ${ }^{95}$ Yet he should not be dismissed lightly for not being a Gesner, a Cornarius, a Vesalius, or a Harvey; that is too simple and too negative a judgement. Rather, we should look for his memorial at the vigour of his response to the traditions he upheld. Consider the last pages of his autobiography, a plea for the highest standards in translation and interpretation: "everyone flies to the Latin translation, none reaches for the Greek, either because there is more profit to be won from the Latin, or because we all want what is not ours, or because, if translations are driving out the originals, one's errors of translation are less easily detected. Galen's writings are full of genius: they must be preserved from the perils of translation by enlarging the number of those who know Greek, by the production of better texts based on older and better manuscripts, by universal scholarly cooperation, and by a wider appreciation of the difficulties of a translation in expressing clearly all the ambiguities and idiom of a particular style. Only then would science flourish in the schools of medicine, the health of mortals be preserved, and life and vigour prolonged."96 Consider too the enthusiasm of Caius in his zoological treatises on English dogs and rare animals, when he can describe to his friend Gesner animals, fish, or plants unknown to or neglected by that great scholar, but which he saw in his tours through England or in noblemen's zoos in London, Warwick, Kenilworth,

"1 A good example is his discovery of the source of the corruptions at the end of "On prognosis", see C. M. G. V. 8. 1, p. 229; this may give greater weight to the possibility that in that tract MS. L was the parent of MS. M, and not, as I argued in my edition, its uncle or cousin.

${ }^{92}$ For the Basle editors, see C. M. G. V. 2.1 (1971), p. 27; V. 8. 1, p. 42: V. 10. 3, p. 41 : we await a promised paper on Ricci by R. J. Durling, (cf. his article, op. cit., note 13 above, p. 105).

${ }^{23}$ For this estimate of Cornarius, cf. C. M. G. V. 9. 1, p. XXI ff.; V. 8. 1, p. 45; E. Wenkebach, 'Pseudogalenische Kommentare zu den Epidemien des Hippokrates', Abh. Preuss. Akad. Wiss., 1917, Phil.-, hist. Kl., 1: 8-12, 53f.: his marginalia were in part published by C. G. Gruner, Iani Cornarii coniecturae et emendationes Galenicae, Jena, 1789, and copied (in the nineteenth century?) in Leipzig University, MS. gr. 58.

os In fairness to Caius, it should be pointed out that if all we had of the writings of J. J. Scaliger were his Galenic annotations, his high reputation would be lowered considerably.

${ }^{95}$ Caius, De pronunciatione, pp. 5-8, citing many classical authors and precedents against change.

96 De libris propriis, pp. 103-105; cf. the similar plea of Cornarius, Hippocratis opera omnia, Basle, Froben, 1546, fol. 4v: "I have always been of the opinion that writers are better studied in their own tongue than in even the best of translations. But what are those who know no Greek to do? When must we see the age when all students of medicine alike can read and understand the Greek Hippocrates?" 


\section{Vivian Nutton}

and elsewhere. ${ }^{97}$ Nor can one miss his obvious desire, in writing his counsel against the sweat, to provide speedy, simple, and effective advice to the sick in general: the combination of forceful practicality and accurate observation (not forgetting some ambitious autobiography ${ }^{98}$ impresses any reader of the English treatise. His Latin version offers a rare and informative insight into what he thought suitable for an academic and European audience: it is longer, elegant rather than powerful, and its bare facts are adorned with the appropriate flowers of learning, both medical and antiquarian. ${ }^{99}$ Caius was a great antiquarian and a vigorous defender of institutions and traditions, whether of the pre-eminence of Cambridge University in age and learning, being founded in 375 B.C. by Cantaber, prince of Spain, ${ }^{100}$ or of the old pronunciation of Greek and Latin, or of the privileges of the College of Physicians. In his nine years as President, if we can trust records largely of his own making, he seems to have revived that institution, endowed it with a fresh purpose, and tried to impose its high standards on the medical men of Oxford, Cambridge, and the rest of England. ${ }^{101}$ The reasons for its comparative failure in this enterprise may have lain in the peculiar divisions and attitudes within the English medical profession by comparison with that of Northern Italy, ${ }^{102}$ and in the geographically broader surveillance that he expected his small College to exercise, but this should not blind us to his high-minded intention of introducing to England the best and most modern continental developments. One of his arguments for writing in Latin or Greek expresses neatly this overall aim: "But chiefely, because I wolde geue none example or comforte to my countrie men (whō I wolde be now, as here tofore they have bene, comparable in learnyng to men of other countries) to stonde onely in the Englishe tongue, but to leave the simplicite of thesame, and to procede further in many and diuerse knowleges bothe in tongues and sciences at home and in Vniuersities, to the adournyng of the common welthe, better seruice of their Kyng, \& great pleasure and commodite of their owne selues, to what kinde of life so euer they shold applie them." 103

We should not forget, too, his zeal for anatomy, and for the Galenic unity of physician and surgeon, ${ }^{104}$ and we cannot but admire his piety, his generosity, and his determination in refounding, at first under the cloak of anonymity, his old College, when he saw it sinking into a decline academic, moral, and financial, with its chapel utensils diverted to private use, its College deeds lost or dispersed, and its funds, save for four pounds sixteen shillings, fraudulently diverted by its last master to the pocket of his brother. ${ }^{105}$ His vigour, enthusiasm, and sense of mission, while it might

97 De rariorum animalium historia, pp. 60, 42, 34.

98 The account of Caius' early life which opens the work (and which is later repeated in De libris propriis) fits very oddly with what follows: nor does it establish Caius' credentials as a medical man, except incidentally, but only as a scholar and author.

90 Classical references are many, and he even mentions events in early English history, De ephemera,

p. 74: four pages, pp. 77-81, are devoted to the names for ale, cf. also pp. 88, 90.

100 De antiquitate Cantebrigiensis Academiae, I, p. 28; Historiae Cantebrigiensis Academiae, I, p. 12. 101 Clark, op. cit., note 24 above, pp. 106-124.

102 For an example of the close affinities between doctors and surgeons in North Italy, see R.

Palmer, 'Physicians and surgeons in sixteenth-century Venice', Med. Hist., 1979, 23: $451-460$.

108 A counseill against the sweat, p. 6.

104 Emphasized by W. Langdon-Brown, 'John Caius and the revival of learning', Proc. R. Soc. Med., Sect. Hist. Med., 1941, 35: 61-69.

$106 \mathrm{~J}$. Venn, in Works, p. 20. 


\section{John Caius and the Linacre tradition}

provoke a Warner and a Spencer to an embittered petition to the Chancellor of the University, ${ }^{108}$ also encouraged others to follow him in benevolence and in support for worthy causes. ${ }^{107}$ It was out of friendship and respect for John Caius that in 1571 Archbishop Parker founded a scholarship at Caius for one aspiring student of medicine from King's School, Canterbury, ${ }^{108}$ and it was as holder of this scholarship that Harvey had the opportunity of seeing human dissection performed, perhaps within the walls of the College. ${ }^{109}$ For all their theoretical differences, Caius, I am sure, would lovingly have commended Harvey for his devotion to part of the Linacre tradition, to the study of anatomy, and to the maintenance of the honour and repute of the College of Physicians, of which Harvey also was a member with a sense of obligation to its benefactors. ${ }^{110}$

${ }^{106}$ Ibid., pp. 23-25.

107 His humanist interests were continued in the next century by Theodore Goulston, pace O'Malley, op. cit., note 38 above, p. 45, who claimed that the Linacre tradition died with Caius.

108 Venn, op. cit., note 1 above, p. 229: J. Caius, Annals of Gonville and Caius College, Cambridge University Press, 1904, p. 176 f. Parker was the supervisor of Caius' will, Works, p. 76, cf. also pp. $39,40$.

${ }_{100} \mathrm{G}$. Whitteridge, The anatomical lectures of William Harvey, Edinburgh and London, Livingstone, 1964, pp. $132 \mathrm{f}$., $292 \mathrm{f}$., although where the anatomies of these two scholars took place is unclear.

110 Clark, op. cit., note 24 above, p. 299; the Harveian orator was, among other duties, to commemorate the College's benefactors by name, and exhort others to follow their example. On Harvey and Galen, see W. Pagel, William Harvey's biological ideas, Basle and New York, S. Karger, 1967, pp. 78, 127-136: Harvey, although a man of authority in the College, made no attempt to change the Galenic entrance examination. 